\title{
Quantitative Analysis of the Rate of Geochemical Weathering of Sulfur from Sedimentary Rocks Using Atmospheric Deposition, Concentration and River Discharge Data
}

\section{-A Case Study of the Mountainous Basin of the Tedori River, Japan, over a 16-Year Period}

\author{
Toshisuke Maruyama ${ }^{1}$, Masashi Yoshida ${ }^{1}$, Keiji Takase $^{1}$, \\ Hiroshi Takimoto ${ }^{1}$, Shigeo Ishikawa ${ }^{2}$, Sadao Nagasaka $^{2}$ \\ ${ }^{1}$ Faculty of Environmental Science, Ishikawa Prefectural University, Ishikawa, Japan \\ ${ }^{2}$ College of Bioresource Science, Nihon University, Kanagawa, Japan \\ Email:maruyama@ishikawa-pu.ac.jp
}

Received March 5, 2013; revised April 7, 2013; accepted April 27, 2013

Copyright (C) 2013 Toshisuke Maruyama et al. This is an open access article distributed under the Creative Commons Attribution License, which permits unrestricted use, distribution, and reproduction in any medium, provided the original work is properly cited.

\begin{abstract}
Quantitative analysis of the rate of geochemical weathering of sulfur $(S)$ from sedimentary rocks $(G e o S)$ was conducted using concentration $(C s)$ and discharge $(Q s)$ data from the Tedori River and atmospheric deposition (AtdepS) in the basin. First, $S$ fluxes were calculated using 16 years of $C s$ and $Q s$ data. The annual average discharge of $S$ (Total $S$ ) was

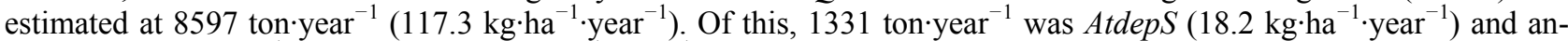
other 7266 ton $\cdot$ year $^{-1}$ was GeoS $\left(99.1 \mathrm{~kg} \cdot \mathrm{ha}^{-1} \cdot \mathrm{year}^{-1}\right)$. Monthly changes in TotalS were investigated, which showed that GeoS was highest in summer, because of the air temperature, while AtdepS peaked in winter because of seasonal wind. Using $Q s$ and Atdep $S$ corrected for altitude, TotalS, AtdepS and GeoS were estimated at six sites, and among these sites we found that the TotalS per unit area values were random, depending on the site characteristics. In particular, the discharge from the Kuwajima site was remarkably high suggesting that the sedimentary rocks at this site had higher pyrite content than at the other sites. Finally, we also assessed the relationship between the characteristics of sedimentary rocks and $G e o S$ in a range of rivers in the Hokuriku Region, and found that there was a close relationship between concentrations of $\mathrm{SO}_{4}^{2-}$ greater than $10 \mathrm{mg} \cdot 1^{-1}$ and sedimentary rocks containing the pyrite group. In addition, we estimated that the influence of $G e o S$ was present when the concentration of $\mathrm{SO}_{4}^{2-}$ in river water was greater than 2 - 3 $\mathrm{mg} \cdot \mathrm{l}^{-1}$ in the Hokuriku region.
\end{abstract}

Keywords: Sulfur Balance; Wet and Dry Deposition; Sulfur Concentration; Altitude Dependence; Sulfur Discharge from Pyrite

\section{Introduction}

There is great concern about sulfur $(S)$ cycling in a river basin because it is closely related to acid deposition in soil, leads to sulfate contamination of irrigation water and has possible damaging consequences for human health. The $S$ cycle in a mountainous river basin is governed by atmospheric deposition (AtdepS) and geochemical weathering of sedimentary rocks $(\mathrm{GeoS})$. The annual average discharge of $S$ (TotalS) from a basin can be estimated by taking the product of the discharge $(Q s)$ and the concentration of $S(C s)$ in the river.
Based on the above, the objectives of this research were as follows: 1) to establish weathering rates of the sulfur mineral defined as GeoS using $Q s$ and $C s$ of the river and AtdepS in the study area; 2) to estimate TotalS discharge from a river basin at various sites both within and beyond the study area; and 3) to investigate the effect of GeoS from sedimentary rocks on different sulfate concentrations in river.

Many studies on geochemical cycling of $S$ have been conducted, including large-scale marine studies. Jamieson et al. carried out a study on the concentrations of sulfate in seawater from sulfur isotopes in sulfide ore [1], 
while Newton et al. reported large shifts in the isotopic composition of seawater sulfate across the Permian-Triassic boundary in northern Italy [2]. Ooki reported size resolved sulfate and ammonium measurements in marine boundary layer from November 2001 to March 2002 over the North and South Pacific [3].

Much research has also been carried out on sulfur cycling in river basins. For example, Norman et al. examined the biogenetic contribution to aerosols and precipitation using isotopes and oxygen [4]. Elimaers et al. investigated the effects of climate on sulfate fluxes from forested catchments in south-central Ontario [5]. William et al. investigated the change in ion outputs from watersheds resulting from acidification of precipitation [6]. Beaulieu et al. modeled the interactions between water and rocks in the Mackenzie Basin; and highlighted the competition between sulfuric and carbonic acid [7]. Huang et al. investigated weathering and soil formation rates based on geochemical mass balances in a small forested watershed [8].

Mine drainage water has also been studied by many researchers. Budakoglu et al. investigated the distribution of, and contamination from, sulfur-isotopes related to the Baya $\mathrm{Pb}-\mathrm{Zn}$ mine in Turkey [9], while Edraki et al. investigated the hydrochemistry, mineralogy and sulfur isotope geochemistry of acid mine drainage at the Mt. Morgan mine, Australia [10].

This study differs from those documented above, in that it reports the results of quantitative analysis of $T o$ talS in a river, in which GeoS has been estimated quantitatively by analysis of $Q s, C s$ and AtdepS data. To date, there have been very few studies of quantitative analysis of $S$ discharges from river basins [11].

\section{Methods}

\subsection{Fundamental Concept of Our Research}

We collected $Q s$ and $C s$ data of river water and the $A t$ $\operatorname{dep} S$ (wet and dry) in a mountainous basin, to estimate fluxes of GeoS quantitatively, and analyzed the relationships among them. The relationship is relatively simple in mountainous basins when compared with lowland basins, as land use is generally more complicated in lowland basins and may include agricultural land, residential and industrial areas.

The $S$ cycle in this study is based on the hypothesis that the Total (the product of $Q s$ and $C s$ ) is consist of AtdepS and GeoS in locations where there is little artificial disturbance (Figure 1). Among them, GeoS is a source of $S$ from inside and AtdepS is an input of $S$ from outside of the basin. The hypothesis contains the change in storage of $S$ in the basin is negligible small due to $A t$ $\operatorname{dep} S$ without including GeoS, In other words, this study assumes a steady state, in which the effect of AtdepS in

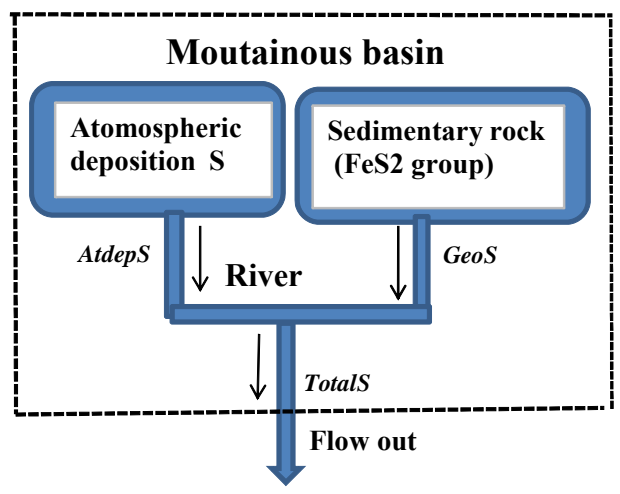

Figure 1. Flow of sulfur $(S)$ in mountainous basin.

the study area remained constant during the study period. On the other hand, river basin usually has sedimentary rock layers, which sometimes contain $S$ compounds. These layers will have been subject to long-term weathering, resulting in the release of $\mathrm{SO}_{4}^{2-}$ into the river.

This research procedure consists of the three following steps:

1) Estimation of the total outflow of $S$ (TotalS) from a test basin using $Q s$ and $C s$;

2) Estimation of AtdepS using $\mathrm{SO}_{4}^{2-}$ atmospheric deposition data measured near the test basin;

3) Estimation of GeoS by subtracting the AtdepS from the TotalS.

To verify the relationships mentioned above, longterm data are required to 1) eliminate the short-term variation in stored $S$ inside of the basin, and 2) minimize the influence of high flows through flooding periods on $C s$ concentrations. In other words, the $S$ cycle is assumed to be in a dynamic steady state as follows: If AtdepS is deposited into a basin, the $S$ will be distributed throughout the soil, water, grass, trees and wild animals. The forest (basin) will gradually become saturated with $S$, and the excess $S$ from Atdep $S$ will then flow out to the river. If this $S$ cycle continues over a prolonged period, the flow of $S$ in the forest will approach a steady state. Based on the above hypothesis, Atdep $S$ data for a 16-year period (divided into yearly intervals) were analyzed. We applied the approach which has been taken in the nitrogen balance analysis already $[12,13]$. Because the sulfur and nitrogen ions may behave in a similar manner, we applied the same procedure to sulfur analysis.

\subsection{Research Site}

The research site is located in the southern part of Ishikawa prefecture, Japan. The research river is the Tedori River which has an area of $809 \mathrm{~km}^{2}$, as shown in Figure 2. The source of the river is at Mount Hakusan, which has an altitude of $2702 \mathrm{~m}$, and flows down a ravine between mountains to Nakajima point (at which point the basin area is $733 \mathrm{~km}^{2}$ ), from where the river flows 


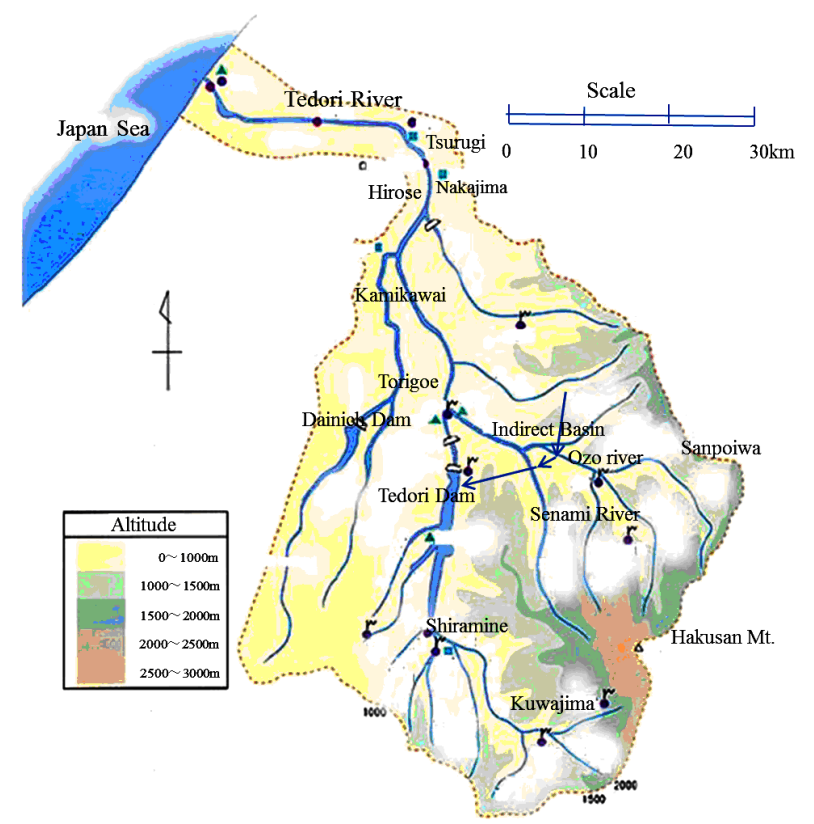

Figure 2. The upland area of the Tedori river basin and the discharge $(Q s)$ and total nitrogen concentration (Cs) monitoring sites.

through an alluvial fan into the Sea of Japan. The alluvial area comprises developed fertile agricultural land and important industrial and residential areas, all of which are supported by surface water and groundwater from the Tedori River.

Plant cover in the basin varies according to the altitude. There is a mountainous belt (altitude $400-1500 \mathrm{~m}$ ), a semi-high mountain belt $(1500-2000 \mathrm{~m})$ and a high mountain belt $(>2000 \mathrm{~m})$. The upstream area belongs to the high mountain belt, is dominated by the Hakusan National Park and is covered with low height pine trees. In the semi-high mountain belt there is high mountain grass, known as flower meadow. Betula Ermanii Chanisso and Abies Mariesii Mast are typical of this area, with the former tree more common in higher areas than the latter. In the mountainous area, there are mature high quality beech trees, while Quercus Crisoula Blume and Japan Marple are found in the lowland areas. Red pine trees are found on ridges and cedars are found in the valley areas of mountains [14-16].

The catchment is in an area of high precipitation, and the annual average precipitation recorded at Kanazawa is $2348 \mathrm{~mm}$. Of this total, $1059 \mathrm{~mm}$ falls between April and September, while $1289 \mathrm{~mm}$ falls from October to May, including much snowfall. The average temperature is $14.9^{\circ} \mathrm{C}$, with an average maximum of $26.1^{\circ} \mathrm{C}$ recorded in August and an average minimum of $4.0^{\circ} \mathrm{C}$ recorded in January.

\subsection{Investigation of AtdepS, Cs and Qs}

The AtdepS was monitored weekly by the Ishikawa pre- fectural government over a 16 year period at the Taiyougaoka site, located at an altitude of $120 \mathrm{~m}$ and at a distance of $10 \mathrm{~km}$ from the study area [17]. The samples were collected by a $20 \mathrm{~cm}$ diameter rain gauge. The $S$ in AtdepS was analyzed by the ion chromatograph method.

In addition to wet deposition, there is dry deposition of $S$ from the atmosphere, which was investigated only for 5 years from 2003 to 2007 [18-21]. To account for dry deposition in other years, the average of the dry deposition of $S$ data collected was added to wet deposition of the other years because the ratio of dry deposition to wet deposition was very small.

Furthermore, the AtdepS (wet deposit) was investigated at Torigoe, located close to the center of the study area, over 7-year period (1997 and 1999-2004) [17]. When compared with the Taiyougaoka and Taiyougaoka data, similar trends are apparent; therefore we considered that the Taiyougaoka data was sufficiently reliable to be used for estimating the quantity of sulfur even though the observation site was located outside of the study area.

To assess the TotalS in the study area, Cs data (as $\mathrm{SO}_{4}^{2-}$ ) was collected at the following six sites (Figure 2): the Hirose site located near the Nakajima discharge observation site, the Tedori dam site located at the No. 1 Hydroelectric Power Generation Station just downstream of the Tedori dam, and the Kamikawai site located downstream of the Dainichi dam. The Senami site is located at the water outlet of the Senami and the Ozo rivers because the basin was changed so that it flows into the Tedori dam. The Shiramine site is located in the upstream section of the Tedori River and the Kuwajima site is at the intake for the Kuwajima Hydroelectric Power Generation Station.

Cs was sampled monthly from 1994 to 2003 and quarterly after 2004 (May, August, November, February), except at the Tedori dam site, where monthly sampling continued after 2004. $\mathrm{SO}_{4}^{2-}$ was measured by the ion chromatograph method. The data were reported in an Annual Report by the Ishikawa Water Supply Office of the Tedori River [21].

The Qs was recorded at the Nakajima site, which is located in the lower reaches of the basin near the Hirose site (Figure 2). The $Q s$ data were supplied by the Hokuriku Hydroelectric Company. The TotalS outflow from the basin was estimated by multiplying the $Q s$ and $C s$.

\subsection{Altitude Correction for Qs and AtdepS}

To estimate the TotalS at the above six sites, $Q s$ and $A t$ depS had to be corrected for $Q s$ and AtdepS based on the altitude because both are strongly affected by basin height. Full details of how we analyzed the altitude dependence of $Q s$ and AtdepS are available elsewhere [12, 13], but brief details of the procedure are as follows: 
The altitude correction was conducted at $200 \mathrm{~m}$ intervals. To make the calculation simple, the weighted central height of the basin was obtained previously by the following formula.

$$
H c=\frac{1}{A} \sum_{i=1}^{n}(H i \times A i)
$$

Here, $H c(\mathrm{~m})$ is the central altitude within the $200 \mathrm{~m}$ belt weighted area, $H i(\mathrm{~m})$ is the central altitude of the each belt, $A i$ (ha) is the area of the belt, $n$ is the number of belts and $A$ (ha) is the total area of the test basin sites.

The $H c$ for relevant test sites is shown in Table $\mathbf{1}$.

\subsubsection{Altitude Dependence of $Q \boldsymbol{s}$}

$Q s$ in the Tedori River basin at Kanazawa was not recorded, but was estimated using precipitation minus evapotranspiration. The evapotranspiration was estimated by complementary relationship using the Penman equation. The result was obtained using 16 years data.

The relationship between the two sites is:

$$
\begin{gathered}
Q s(\text { Nakajima })=1.153 Q s(\text { Kanazawa })+1406 \\
\left(R^{2}=0.689, p=0.0007\right)
\end{gathered}
$$

Here, the unit of $Q s$ is mm year $^{-1}$.

The altitude dependence of $Q s$ between sites at Kanazawa ( $Q s$ is $1603 \mathrm{~mm} \cdot$ year $^{-1}$ and $H c$ is $7 \mathrm{~m}$ ) and Nakajima ( $Q s$ is $3299 \mathrm{~mm} \cdot \mathrm{year}^{-1}$ and $H c$ is $943 \mathrm{~m}$ ) was determined by a straight line passing through the altitude and the $Q s$ of two sites Figure 3. The following experimental formula was obtained:

$$
Q s=1.757 H c+1594
$$

To estimate $Q s$ at relevant sites, the experimental Formula (3) was rewritten by standardization with Nakajima site which have investigated $Q s$ data.

$$
\frac{Q s}{Q s(\text { Nakajima })}=0.000540 H c+0.4908
$$

The relative $Q s[Q s / Q s$ (Nakajima)] was shown in Table 1 for estimation of $Q s$ at the relevant sites.

\subsubsection{Altitude Dependence of AtdepS}

The altitude dependence of AtdepS between Taiyougaoka and Sanpoiwa was based on the average of 7 years' data from June to October as shown in Figure 4 (1995-2001) [17]. The relationship is:

$$
\operatorname{Adep} S(\text { Sanpoiwa })=0.554 \operatorname{Atdep} S(\text { Taiyougaoka })
$$

where, unit of AtdepS is $\mathrm{kg} \cdot \mathrm{ha}^{-1} \cdot 5 \mathrm{month}^{-1}$.

The experimental formula was applied for entire year. The average of observed AtdepS at Taiyougaoka was $25.08 \mathrm{~kg} \cdot \mathrm{ha}^{-1} \cdot \mathrm{year}^{-1}$ and the AtdepS of Sanpoiwa was $13.89 \mathrm{~kg} \cdot \mathrm{ha}^{-1} \cdot$ year $^{-1}$ estimated by Equation (5), then, the altitude dependence was determined by a straight line passing through the above two AtdepS values and each altitude (Taiyougaoka altitude $H c$ is $120 \mathrm{~m}$ and Sanpoiwa altitude $H c$ is $1450 \mathrm{~m}$ above sea level respectively). The experimental formula was obtained as follows:

$$
\text { AtdepS }=26.09-0.00841 H c
$$

where, the unit of AtdepS is $\mathrm{kg} \cdot \mathrm{ha}^{-1} \cdot \mathrm{year}^{-1}$ at any altitude $H c(\mathrm{~m})$.

To estimate AtdepS at relevant sites, the experimental Formula (6) was rewritten by standardization with Taiyougaoka site which have investigated AtdepS data.

$$
\frac{\text { Atdep } S}{\text { AtdepS }(\text { Taiyougaoka })}=1.040-0.000335 \mathrm{Hc}
$$

The relative AtdepS [AtdepS/AtdepS (Taiyougaoka)] was shown in Table 1 for estimation of AtdepS at relevant sites.

The basin areas for relevant $C s$ observation sites, the height of the center $(\mathrm{Hc})$ of the relevant basins, the relative discharge based on Nakajima data calculated by Equation (4) and the relative AtdepS based on Taiyougaoka data calculated by Equation (7) at relevant sites are shown in Table 1.

\section{Results}

\subsection{Total $S$ from Test Basin}

Table 2 shows the statistical features of $Q s, C s$ and Total $S$

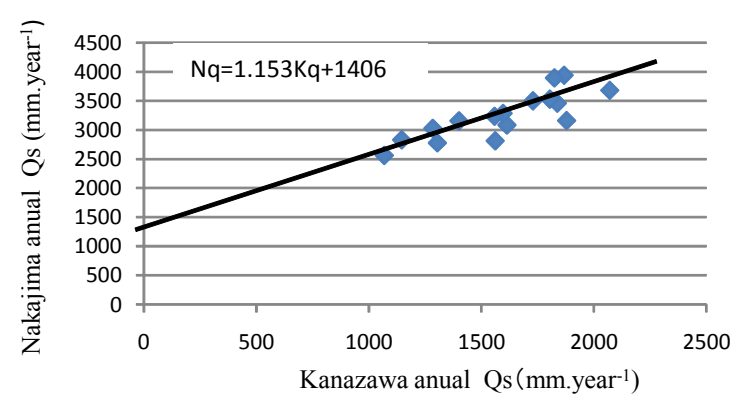

Figure 3. Relationship between $Q s$ at Nakajima and Kanazawa $\left(\mathrm{mm} \cdot \mathrm{year}^{-1}\right)$.

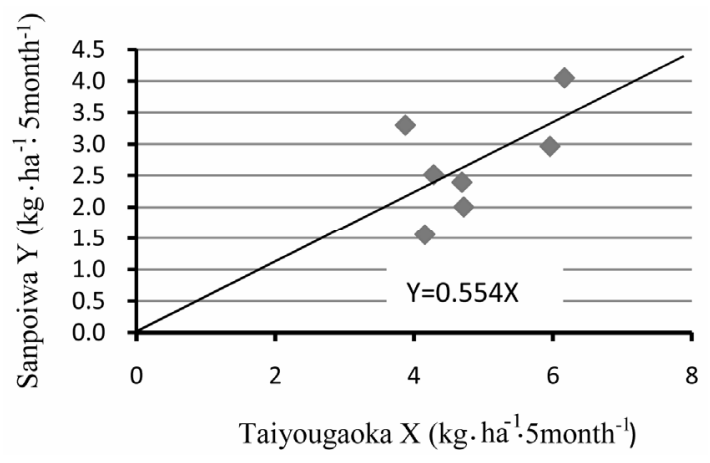

Figure 4. AtdepS relationship between Sanpoiwa and Taiyougaoka. 
Table 1. Basin area, Hc, relative deposition (AtdepS)/Adeps (Taiyougaoka) and discharge (Qs)/Qs (Nakajima).

\begin{tabular}{cccccccccc}
\hline & Name & Nakajima & \multicolumn{2}{c}{ Tedori dam site } & Dainich & Shiramine & Senami & Kuwajima & Standard \\
\cline { 2 - 8 } Items & (Hirose) & Indirect basin & Direct basine & Dam site & & (Ozo) & & Sites \\
\hline Basin area (ha) & 73,307 & 42,836 & 24,723 & 8392 & 16,185 & 17,966 & 8335 & \\
Hc (m) & 943 & 1179 & 1052 & 733 & 1177 & 1359 & 1390 & 0.574 & Taiyougaoka \\
Relative AtdepS & 0.724 & 0.645 & 0.687 & 0.795 & 0.646 & 0.584 & 1.225 & 1.242 & Nakajima \\
Relative $Q s$ & 1.000 & 1.128 & 1.059 & 0.886 & 1.126 & 1.225 & \\
\hline
\end{tabular}

Table 2. Statistical features for Qs, Cs, TotalS and unit load at the Hirose site (Nakajima).

\begin{tabular}{cccccc}
\hline Items & Unit & Average & Min & Max & CV (\%) \\
\hline$Q s$ & $\mathrm{~mm} \cdot \mathrm{year}^{-1}$ & 3047 & 2445 & 3810 & 13.5 \\
Cs & $\mathrm{mg} \cdot l^{-1}$ & 3.86 & 2.7 & 4.6 & 12.7 \\
TotalS & ${\text { ton } \cdot \mathrm{year}^{-1}}^{-1}$ & 8597 & 6436 & 12,046 & 16.6 \\
Unit load & $\mathrm{kg} \cdot \mathrm{ha}^{-1} \cdot \mathrm{year}^{-1}$ & 117.3 & 87.8 & 164.3 & 16.6 \\
\hline
\end{tabular}

over 16 years of the test period. $Q s$ ranged from 2445 $\mathrm{mm} \cdot \mathrm{year}^{-1}$ to $3810 \mathrm{~mm} \cdot \mathrm{year}^{-1}$, with an average of 3047 mm.year ${ }^{-1}$ (coefficient of variation c.v 13.5\%). The $C s$ ranged from $2.7 \mathrm{mg} \cdot l^{-1}$ to $4.6 \mathrm{mg} \cdot l^{-1}$, with an average of $3.86 \mathrm{mg} \cdot 1^{-1}$ while TotalS ranged from 6436 ton year $^{-1}$ to 12,046 ton $^{\text {year }}{ }^{-1}$, with an average of 8597 ton $^{\prime}$ year $^{-1}$.

Figure 5 shows the temporal and yearly change of $T o$ talS in unit area over the test period, which was divided into GeoS and AtdepS, ranged from $87.8 \mathrm{~kg} \cdot \mathrm{ha}^{-1}$ to 164.3 $\mathrm{kg} \cdot \mathrm{ha}^{-1}$, with an average of $117.3 \mathrm{~kg} \cdot \mathrm{ha}^{-1}$. GeoS ranged from $72.8 \mathrm{~kg} \cdot \mathrm{ha}^{-1}$ to $146.5 \mathrm{~kg} \cdot \mathrm{ha}^{-1}$ with an average of $99.1 \mathrm{~kg} \cdot \mathrm{ha}^{-1}$ and c.v of $20.1 \%$. AtdepS ranged from 14.9 $\mathrm{kg} \cdot \mathrm{ha}^{-1}$ to $22.7 \mathrm{~kg} \cdot \mathrm{ha}^{-1}$ with an average of $18.2 \mathrm{~kg} \cdot \mathrm{ha}^{-1}$ and c.v of $11.4 \%$.

Table 3 shows the average monthly changes in $Q s, C s$ and TotalS over the test period. Qs ranged from $130 \mathrm{~mm}$ to $431 \mathrm{~mm}$, with an average of $254 \mathrm{~mm}$ (c.v is $38 \%$ ). Cs ranged from $2.15 \mathrm{mg} \cdot \mathrm{l}^{-1}$ to $5.25 \mathrm{mg} \cdot \mathrm{l}^{-1}$, with an average of $3.97 \mathrm{mg} \cdot \mathrm{l}^{-1}$. Total $S$ ranged from 387 ton to $1235 \mathrm{ton}$, with an average of 700 ton. Unit load ranged from 5.25 $\mathrm{kg} \cdot \mathrm{ha}^{-1}$ to $16.85 \mathrm{~kg} \cdot \mathrm{ha}^{-1}$ with an average of $9.55 \mathrm{~kg} \cdot \mathrm{ha}^{-1}$ (c.v is $31.7 \%$ ).

\subsection{Feature of AtdepS}

Annual AtdepS are shown in Table 4. TotalS ranged from $20.5 \mathrm{~kg} \cdot \mathrm{ha}^{-1}$ to $31.3 \mathrm{~kg} \cdot \mathrm{ha}^{-1}$, with an average of $25.1 \mathrm{~kg} \cdot \mathrm{ha}^{-1}$. Wet deposition ranged from $18.5 \mathrm{~kg} \cdot \mathrm{ha}^{-1}$ to $29.5 \mathrm{~kg} \cdot \mathrm{ha}^{-1}$, with an average of $23.1 \mathrm{~kg} \cdot \mathrm{ha}^{-1}$.

\subsection{TotalS Load for Relevant Sites}

The TotalS load of the six sites with different altitudes in the study area are shown in Figure $\mathbf{6}$ dividing into GeoS and AtdepS, to which altitude correction had already been applied, by the relevant unit areas. The TotalS was based
Table 3. Statistical features of monthly changes in Qs, Cs and TotalS at the Hirose site (Nakajima).

\begin{tabular}{cccccc}
\hline Items & Unit & Average & Min & Max & c.v (\%) \\
\hline$Q s$ & $\mathrm{~mm} \cdot \mathrm{month}^{-1}$ & 254 & 130 & 431 & 38.0 \\
Cs & $\mathrm{mg} \cdot \mathrm{l}^{-1}$ & 3.97 & 2.15 & 5.25 & 22.4 \\
TotalS & ${\text { ton } \cdot \mathrm{month}^{-1}}^{-1}$ & 700 & 387 & 1235 & 31.7 \\
Unit load & $\mathrm{kg} \cdot \mathrm{ha}^{-1} \cdot \mathrm{month}^{-1}$ & 9.55 & 5.29 & 16.9 & 31.7 \\
\hline
\end{tabular}

Table 4. Statistical features of AtdepS at the Hirose site (Na-

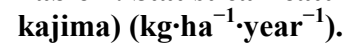

\begin{tabular}{ccccc}
\hline Items & Average & Min & Max & c.v (\%) \\
\hline Wet AtdepS & 23.1 & 18.5 & 29.5 & 12.2 \\
Dry AtdepS & 2.0 & 0.5 & 3.2 & 26.3 \\
Total AtdepS & 25.1 & 20.5 & 31.3 & 11.4 \\
\hline
\end{tabular}

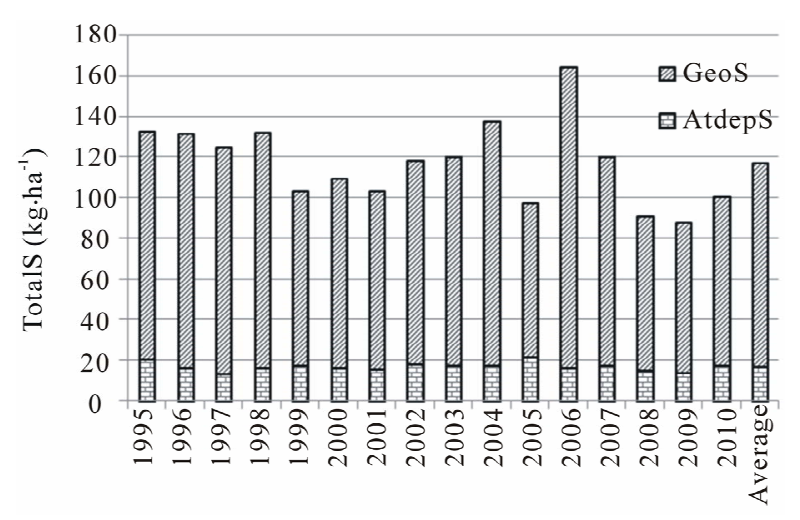

Figure 5. Temporal change in TotalS by unit area at the Hirose site (Nakajima).

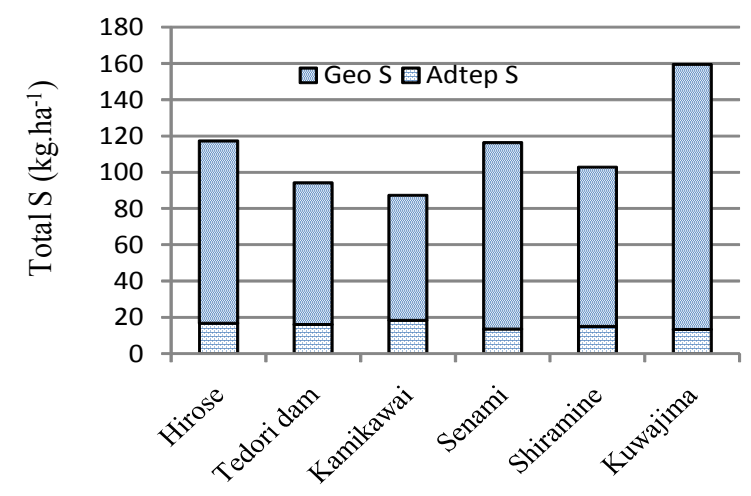

Figure 6. Comparison of AdtepS and GeoS at relevant sites. 
on the observed $C s$ and the estimated $Q s$ data from the Nakajima site. GeoS occupied large part of TotalS of relevant sites. TotalS shows variation between sites, but does not show any distinct trends as were observed in nitrogen concentrations, such as upstream sites having lower concentrations than downstream sites $[12,13]$. The TotalS for the Kuwajima site are particularly high, probably attributable to geological factors.

\subsection{Comparison of AtdepS and GeoS}

Figure 7 shows the monthly changes in the average concentrations of AtdepS and GeoS over the test period at the Hirose site. The GeoS concentration was about 5.46 times greater than the AtdepS concentration. The maximum AtdepS concentration occurred in the winter season because of seasonal wind from continental Asia, while the GeoS had its peak in summer, however the value for $G e o S$ was relatively flat compared with that of AtdepS. Concentrations at the remaining five sites show similar patterns to those at the Hirose site.

Figure 8 shows the monthly changes of AtdepS and $G e o S$ loads at the Hirose site. The AtdepS peaks in the winter season for the same reason as $C s$, while GeoS peaks in summer, because rapid chemical reactions may be caused by the high temperature. The remaining five sites in the study area show the same patterns in TotalS similar to those at the Hirose site.

Table 5 shows the TotalS, the average load by unit area and the percentage of contributions from GeoS and

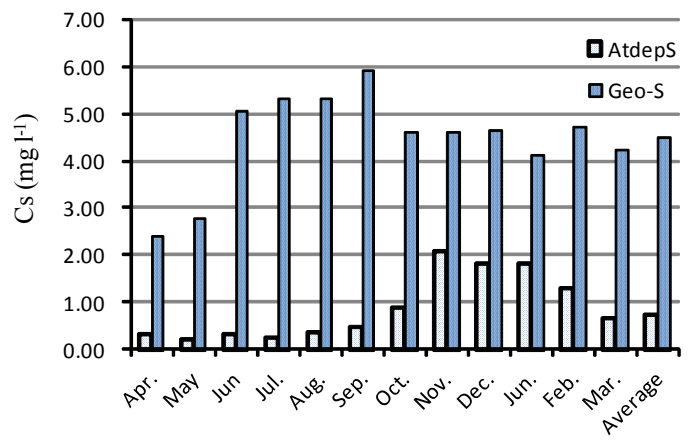

Figure 7. Monthly changes in GeoS and AtdepS concentrations at Hirose (Nakajima) site.

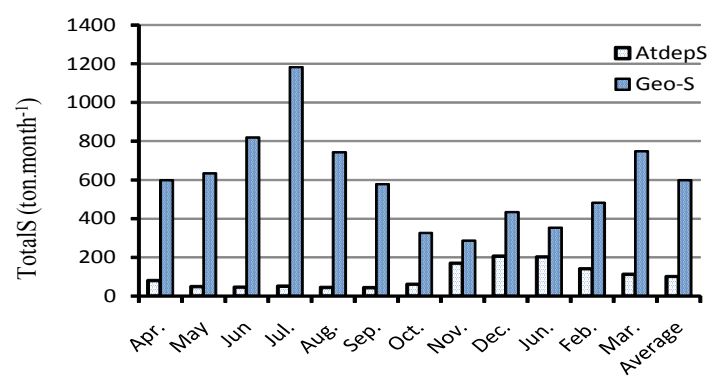

Figure 8. Monthly changes in AtdepS and GeoS loads at Hirose (Nakajima) site.
AtdepS over 16 years. At the Hirose site, the TotalS discharge was estimated at 8597 ton $^{-}$year $^{-1}$, resulting in a unit load of $117.3 \mathrm{~kg} \cdot \mathrm{ha}^{-1} \cdot \mathrm{year}^{-1}$, of which the AtdepS load was $18.2 \mathrm{~kg} \cdot \mathrm{ha}^{-1} \cdot$ year $^{-1}(15.5 \%)$ and the GeoS load was $99.1 \mathrm{~kg} \cdot \mathrm{ha}^{-1} \cdot \mathrm{year}^{-1}(84.5 \%)$.

\section{Discussion}

\subsection{Geological Features of the Study Catchment and Process of $\mathrm{SO}_{4}^{2-}$ Production from Sedimentary Locks}

To help explain the reason for the large percentage of $S$ from GeoS in TotalS, we examined the geological map of this area (shown in Figure 9 [22]).

The upstream area of this basin contains a sedimentary rock layer named the "Tedori sedimentary layer group", which was formed during the Cretaceous period about $180-110$ million years ago. The layer seemed to have formed under the Sea of Japan at that time, and contained $S$ compounds from the pyrite $\left(\mathrm{FeS}_{2}\right)$ group. In fact, the Ogoya mine, which was in operation until 1971 and from which chalcopyrite was extracted for about 100 years, is located outside of the test basin. The sedimentary rock layer released $\mathrm{SO}_{4}^{2-}$ by oxidation because of the presence of a canyon in the Tedori River basin.

There are three oxidation processes that produce $\mathrm{SO}_{4}^{2-}$ as following two forms [23]:

(1) Oxidation process of pyrite $\left(\mathrm{FeS}_{2}\right)$

$$
\begin{gathered}
2 \mathrm{FeS}_{2}+\mathrm{O}_{2}+4 \mathrm{H}^{+} \rightarrow 2 \mathrm{Fe}^{2+}+4 \mathrm{~S}^{0}+2 \mathrm{H}_{2} \mathrm{O} \\
4 \mathrm{Fe}^{2+}+\mathrm{O}_{2}+4 \mathrm{H}^{+} \rightarrow 4 \mathrm{Fe}^{3+}+2 \mathrm{H}_{2} \mathrm{O} \\
2 \mathrm{~S}^{0}+3 \mathrm{O}_{2}+2 \mathrm{H}_{2} \mathrm{O} \rightarrow 2 \mathrm{SO}_{4}^{2-}+4 \mathrm{H}^{+}
\end{gathered}
$$

The first process rapidly progresses in the presence of sulfur and iron bacteria (Thiobacillus ferrooxidans or Ferrobacillus ferrooxidans). The second process also rapidly progresses in the presence of bacteria (Thiobacilli containing Thiobaccillus thiooxidans). The third reaction will progress under acidic conditions, and as a result, $\mathrm{SO}_{4}^{2-}$ is formed.

(2) Oxidation of pyrite

$$
\begin{gathered}
\mathrm{FeS}_{2}+2 \mathrm{Fe}^{3+} \rightarrow 3 \mathrm{Fe}^{2+}+2 \mathrm{~S}^{0} \\
2 \mathrm{~S}^{0}+12 \mathrm{Fe}^{3+}+8 \mathrm{H}_{2} \mathrm{O} \rightarrow 12 \mathrm{Fe}^{2+}+2 \mathrm{SO}_{4}^{2-}+16 \mathrm{H}^{+}
\end{gathered}
$$

Table 5. TotalS, AtdepS and GeoS loads and unit area loads at Hirose site (Nakajima).

\begin{tabular}{cccc}
\hline \multirow{2}{*}{ Items } & Total & Unit area & Percentage \\
\cline { 2 - 4 } & ${\text { ton } \cdot \mathrm{year}^{-1}}$ & $\mathrm{~kg} \cdot \mathrm{ha}^{-1} \cdot \mathrm{year}^{-1}$ & $(\%)$ \\
\hline TotalS & 8597 & 117.3 & 100 \\
AtdepS & 1331 & 18.2 & 15.5 \\
GeoS & 7266 & 99.1 & 84.5 \\
\hline
\end{tabular}


(3) Formation of Jarosite and goethite

In addition to the processes outlined in (1) and (2) above, the following process also occurs.

$$
\begin{gathered}
3 \mathrm{Fe}(\mathrm{OH})_{2}^{+}+2 \mathrm{SO}_{4}^{2-}+\mathrm{K}^{+} \rightarrow \mathrm{KFe}_{3}\left(\mathrm{SO}_{4}\right)_{2}(\mathrm{OH})_{6} \\
\mathrm{KFe}_{3}\left(\mathrm{SO}_{4}\right)_{2}(\mathrm{OH})_{6} \rightarrow 3 \mathrm{FeOOH}+2 \mathrm{SO}_{4}^{2-}+\mathrm{K}^{+}+3 \mathrm{H}^{+}
\end{gathered}
$$

In the first reaction above, $\mathrm{KFe}_{3}\left(\mathrm{SO}_{4}\right)_{2}(\mathrm{OH})_{6}$ (Jarosite) is formed, and the Jarosite then reacts to form of $\mathrm{SO}_{4}^{2-}$ again, as shown in the second reaction, along with $3 \mathrm{FeOOH}$ (Goethite). Here, the $\mathrm{SO}_{4}^{2-}$ ion is indicated with an underline.

\subsection{Cs in Rivers in the Hokuriku Region}

To investigate the difference of the sedimentary rock characteristics, we investigated the $C s$ concentrations in the rivers in the Hokuriku region, which has quite similar conditions for AtdepS as our study area. Kobayashi reported the presence of the $\mathrm{SO}_{4}^{2-}$ ion in many rivers throughout Japan [24]. Table 6 gives information on the $\mathrm{SO}_{4}^{2-}$ ion concentration in many rivers in Toyama, Ishikawa and Fukui prefectures. These three prefectures face toward the Sea of Japan and receive seasonal wind from the Asian Continent meaning that the conditions for AtdepS are quite similar.

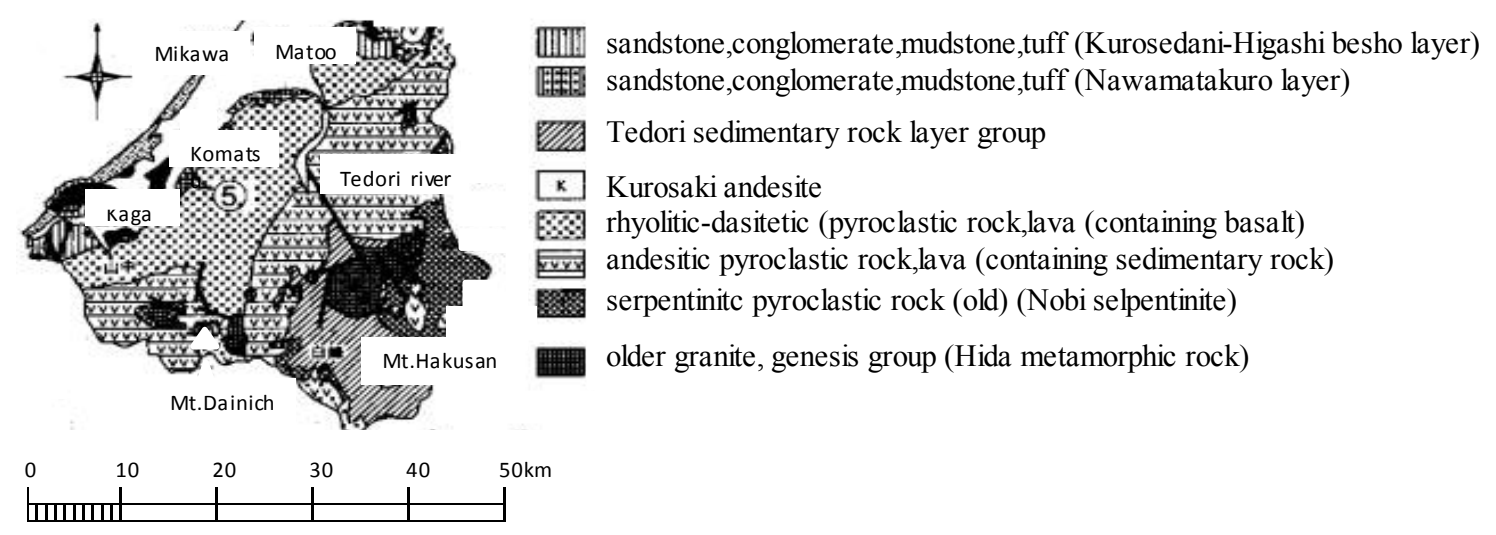

Figure 9. Geological map of study area [21].

\begin{tabular}{|c|c|c|c|c|c|}
\hline \multirow{2}{*}{ Prefecture } & \multirow{2}{*}{ River name } & \multirow{2}{*}{ Sampling sites } & \multirow{2}{*}{$\begin{array}{c}\mathrm{SO}_{4}^{2-} \\
\left(\mathrm{mg} \cdot l^{-1}\right)\end{array}$} & \multirow{2}{*}{$\mathrm{pH}$} & \multirow{2}{*}{ Geological feature at upstrem } \\
\hline & & & & & \\
\hline \multirow[t]{7}{*}{ Toyama } & Kurobe & Unatsuki Town, Shimoshinkawa Province & 5.9 & 7.2 & \\
\hline & Katakai & Kurodani, Uozu City & 1.9 & 7.2 & \\
\hline & Hayatsuki & Namerikawa City & 3.3 & 7.2 & \\
\hline & Jougannji & Tateyama Town, Nakashinkawa Province & 14.0 & 7.3 & Tedori sedimentary rock group \\
\hline & Jintsu & Oosawano Town, Kamishinkawa Province & 4.6 & 7.3 & \\
\hline & Shoukawa & Shoukawa Town, Higashitonami Province & 4.7 & 7.3 & \\
\hline & Oyabe & Fukumitsu Town, Nishitonami Province & 3.3 & 6.9 & \\
\hline \multirow[t]{6}{*}{ Ishikawa } & Wakayama & Furukura, Wakamatsu Town, Suzu City & 24.0 & 6.7 & Diatomaceous earth area \\
\hline & Nagaso & Kasai Town, Kashima Province & 27.0 & 7.1 & \\
\hline & Saikawa & Hamagurisaka Town, Kanazawa City & 5.9 & 7.1 & \\
\hline & Tedori & Tsurugi Town, Ishikawa Province & 10.7 & 7.4 & Tedori sedimentary rock group \\
\hline & Kakehasi & Karumi Town, Komatsu City. & 34.2 & 6.6 & Tedori sedimentary rock group \\
\hline & Daishoji & Yamanaka Town, Enuma Province & 9.5 & 7.0 & \\
\hline \multirow[t]{7}{*}{ Fukui } & Kuzuryu & Eiheiji Town, Yoshida Province & 3.3 & 7.2 & \\
\hline & Ashiba & Ashiba Town, Ashiba Province & 3.3 & 7.2 & \\
\hline & Hinokawa & Nakahirabuki Town, Takefu City & 3.3 & 7.1 & \\
\hline & Sasano & Tsuruga City & 3.0 & 7.1 & \\
\hline & Mimikawa & Mihama Town, Mikata Province & 3.7 & 7.1 & \\
\hline & Kitakawa & Miyake, Kaminaka Town, Onyu Province & 3.6 & 7.1 & \\
\hline & Minamikawa & Nakai, Obama City & 2.7 & 7.0 & \\
\hline
\end{tabular}

Table 6. Sulfur concentration of river water in Hokuriku Region (Kobayashi 1971) [23]. 
In Table 6, we consider river basins in which the $\mathrm{SO}_{4}{ }^{2-}$ concentrations exceeded $10 \mathrm{mg} \cdot \mathrm{l}^{-1}$, and attempt to explain the elevated concentrations. The high con centration in the Jougangi, Tedori and Kakehashi rivers can be explained by the presence of the Tedori sedimentary rock layer which contains pyrite. The Kakehashi river also has a copper mine company located in its basin. There is an area of diatomaceous earth in the Wakayama which is rich in $\mathrm{S}$ compounds and which contributes to elevated concentrations. The reason for elevated concentrations in the Nagaso is not so clear. We can however confirm from the above that $C s$ concentrations in rivers will be quite high if the basin has a sedimentary rock layer containing $S$, such as the pyrite group.

Our research therefore demonstrates that if the concentration of $\mathrm{SO}_{4}^{2-}$ in the river water exceeds 2 - 3 $\mathrm{mg} \cdot \mathrm{l}^{-1}$ which may be supplied by AtdepS in the Hokuriku region, the river will contain $S$ that originates from sedimentary rocks such as pyrite.

\subsection{Further Research}

There were limited data available for $C s$ due to a lack of sampling, which is of particular concern because $C s$ is strongly dependent on $Q s$. Nitrogen concentrations were also strongly dependent on discharge; however, this was mainly due to changes in organic nitrogen concentrations, while inorganic nitrogen concentrations did not change significantly. Compared with nitrogen outflow, Cs may not change so remarkably because the inorganic nitrogen behavior will be comparable to that of sulfate. However, to rectify the $C s$ data shortage issue, data from as long a time period as possible will be used so as to ensure inclusion of data for a wide range of discharges.

Therefore, more frequent $C s$ sampling is required in future for more reliable results. Further, this research was based on the hypothesis that the sulfur cycle was in a steady state, which is in turn based on an analogy of the nitrogen cycle, and verification of this hypothesis remains as a research issue for the future.

\section{Conclusion}

Based on the hypothesis that $S$ in river water consists mainly of AtdepS and GeoS in mountainous basins, we carried out quantitative analysis of TotalS (the product of $C s$ and $Q s$ ) originating from AtdepS and GeoS. The Tedori River mountainous basin was chosen as a test basin, because 16 years of data for Cs, Qs and AtdepS were available. Furthermore, we also have experience of calculating the nitrogen balance for the same basin $[19,20]$, thus, the procedure for which is comparable to that for the $S$ analysis.

First, TotalS was calculated using $Q s$ and $C s$ data collected over a period of 16 years. The annual average out- flow of the TotalS was estimated at 8597 ton $^{\prime} y$ ear $^{-1}$, which corresponds to an average of $117.3 \mathrm{~kg} \cdot \mathrm{ha}^{-1} \cdot \mathrm{year}^{-1}$. Of this TotalS, AtdepS was 1331 ton year $^{-1}$, corresponding to $18.2 \mathrm{~kg} \cdot \mathrm{ha}^{-1} \cdot \mathrm{year}^{-1}$, and GeoS was 7266 ton. year $^{-1}$, corresponding to $99.1 \mathrm{~kg} \cdot \mathrm{ha}^{-1} \cdot$ year $^{-1}$.

In the above analysis, $Q s$ and AtdepS in the basin have been corrected for altitude using the limited data available, as both precipitation and AtdepS depend on, and vary according to the altitude.

Using the altitude correction method outlined above, the AtdepS was estimated at six sites, namely Kuwajima, Shiramine, Senami, the Tedori dam site, the Dainichi dam site (Kamikawai) and Hirose (Nakajima). At these six sites the TotalS outflow was not constant, although the Atdep of nitrogen showed that deposition in the upper catchment was low and that it gradually increased in the lower reaches of the catchment $[19,20]$. The GeoS load was strongly dependent on the individual site characteristics, and in particular the Kuwajima site showed a remarkably high GeoS load, which suggests that the sedimentary rock at this site has much higher pyrite content than at the other sites.

To help explain why GeoS was higher than AtdepS, we examined the geological map of the study basin and confirmed that the sedimentary rock layer was rich in the pyrite group. Finally, we examined the relationship between the characteristics of sedimentary rocks and GeoS in many rivers in the Hokuriku Region because the climate conditions for AtdepS in this area are quite uniform. From this examination it was clear that $\mathrm{SO}_{4}^{2-}$ concentrations greater than about $10 \mathrm{mg} \cdot l^{-1}$ in river water were closely related to the sedimentary layer containing the pyrite group. In addition, we estimated that $\mathrm{SO}_{4}{ }^{2-}$ concentrations greater than $2-3 \mathrm{mg} \cdot 1^{-1}$ in river water in the Hokuriku region would be influenced by GeoS.

\section{Acknowledgements}

We sincerely thank Professor Okazaki of Ishikawa Prefectural University for commenting on the geochemical reaction of sedimentary rocks and for providing adequate references, and Professor Emeritus Kyuma of Kyoto University for kindly commenting. We also express sincere thanks to the government of Ishikawa Prefecture for providing valuable data. We also express thanks to the co-researchers of a study entitled "Normal hydrologic cycle as a core of irrigation water in the Tedori River basin" at Ishikawa Prefectural University, supported by the Ministry of Agriculture, Forests and Fishery, for their many valuable comments.

\section{REFERENCES}

[1] J. W. Jamieson, B. A. Wing, J. Farquhar and M. D. Hannington, "Neoarchaean Seawater Sulphate Concentrations 
from Sulphur Isotopes in Massive Sulphide Ore," Nature Geosciene, Vol. 6, No. 1, 2013, pp. 61-64.

[2] R. J. Newton, E. L. Pevitt, P. B. Wignall and S. H. Bottrell, "Large Shifts in the Isotopic Composition of Seawater Sulphate across the Permo-Triassic Boundary in Northern Italy," Earth and Planetary Science Letters, Vol. 218, No. 3-4, 2004, pp. 331-345. doi:10.1016/S0012-821X(03)00676-9

[3] A. Ooki, "Size-Resolved Sulfate and Ammonium Measurements in Marine Boundary Layer over the North and South Pacific," Japanese Institutional Repositories, Vol. 41, No. 1, 2007, pp. 81-91.

[4] A. L. Norman, W. Belzer and L. Barrie, "Insights into the Biogenic Contribution to Total Sulphate in Aerosol and Precipitation in the Fraser Valley Afforded by Isotopes of Sulphur and Oxygen," Journal of Geophysical ResearchAtmospheres, Vol. 109, No. D5, 2004. doi:10.1029/2002JD003072

[5] M. C. Eimers and P. J. Dillon, "Climate Effects on Sulphate Flux from Forested Catchments in South-Central Ontario," Biogeochemistry, Vol. 61, No. 3, 2002 pp. 337355. doi:10.1023/A:1020261913618

[6] W. M. Lewis Jr. and M. C. Grant, "Changes in the Output of Ions from a Watershed as a Result of the Acidification of Precipitation," Ecology, Vol. 60, No. 6, 1979, pp. 10931097.

[7] E. Beaulieu, Y. Godderis, D. Labat, C. Roelandt, D. Calmels and J. Gaillardet, "Modeling of Water-Rock Interaction in the Mackenzie Basin; Competition between Sulfuric and Carbonic Acids," Elsevier, Amsterdam.

[8] L.-M. Hang, G.-L. Zhang and J.-L. Yang, "Weathering and Soil Formation Rates Based on Geo Chemical Mass Balance in a Small Forested Watersheds under Acid Precipitation in Subtropical China Catena," CATENA, Vol. 105, 2013, pp. 11-20.

[9] M. Budakoglu, "Sulfur-Isotope Distribution and Contamination Related to the Balya $\mathrm{Pb}-\mathrm{Zn}$ Mine in Turkey," Environmental Geology, Vol. 47, No. 6, 2005, pp. 773781. doi:10.1007/s00254-004-1202-1

[10] M. Edraki, S. D. Golding, K. A. Baublys and M. G. Lawrence, "Hydrochemistry, Mineralogy and Sulfur Isotope Geochemistry of Acid Mine Drainage at the Mt. Morgan Mine Environment, Queensland, Australia," Pergamon
Oxford, New York and Beijing, International, GeoRef.

[11] M. Aikawa, T. Hiraki, Y. Komai, U. Satoshi and N. Tokuch, "A Case Study on Input-Output of Sulfur in a Catchment Area in Japan," Journal of Atmosphere Environment, Vol. 43, No. 1, 2008, pp. 23-30.

[12] T. Maruyama, M. Yoshida, K. Takase, H. Takimoto, S. Ishikawa and S. Nagasaka, "Relationship between Nitrogen Atmospheric Deposition, Discharge and Concentration, and Monthly Change of Those in a River, Japan," Journal of Water Resources and Protection, Vol. 5, No. 3, 2013, pp. 283-293. doi:10.4236/jwarp.2013.53029

[13] T. Maruyama and M. Yoshida, "Relation between Rainfall Deposit, Nitrogen Concentration and Discharge Height," Applied Hydrology, 2013, pp. 1-14.

[14] Shiramine, "History of Shiramine," Vol. 1, 1961, pp. 1820.

[15] Oguch, "History of Oguch," Ishikawa Prefecture, Vol. 1, 1978, pp. 66-74.

[16] Construction Bureau of Hokuriku Region, "Kanazawa Office of Construction Works, History of Flood Control," 1985, pp. 13-15.

[17] Ishikawa Prefecture, "Investigation Report on Environment and Air. 2006-2010," Research Institute of Ishikawa Environment and Health, 2007-2011.

[18] Japanese Association of Environment, "Forth Report of Acid Rainfall in Japan 2005," Environment Research Committee, 2007.

[19] Japanese Association of Environment, "Forth Report of Acid Rainfall in Japan, 2006," Environment Research Committee, 2008.

[20] Japanese Association of Environment, "Forth Report of Acid Rainfall in Japan, 2007," Environment Research Committee, 2009.

[21] Ishikawa Prefecture Water Supply Office of Tedori River, "Annual Report of Water Quality, 1977-2011,"

[22] "Geological Map of Ishikawa Prefecture," www.jisuberi-kyokai.or.jp/kobetu/isikawa/okada/12.html

[23] Tropical Agricultural Center, "Swampy Lowland in SouthAsian Countries," Tropical Agricultural Center, 1986.

[24] J. Kobayashi, "Health Examination of River Water, Iwanami Series," 1971. 